\title{
Prediction of functional phosphorylation sites by incorporating evolutionary information
}

\author{
Shen $\mathrm{Niu}^{1 *}$, Zhen Wang ${ }^{1 *}$, Dongya Ge ${ }^{1 *}$, Guoqing Zhang ${ }^{1,2} \bowtie$, Yixue $\mathrm{Li}^{1,2} \bowtie$ \\ ${ }^{1}$ Key Laboratory of Systems Biology, Shanghai Institutes for Biological Sciences, Chinese Academy of Sciences, Shanghai \\ 200031, China \\ 2 Shanghai Center for Bioinformation Technology, Shanghai 200235, China \\ $\bowtie$ Correspondence: gqzhang@scbit.org (G. Zhang), yxli@sibs.ac.cn (Y. Li) \\ Received May 21, 2012 Accepted June 27, 2012
}

\begin{abstract}
Protein phosphorylation is a ubiquitous protein post-translational modification, which plays an important role in cellular signaling systems underlying various physiological and pathological processes. Current in silico methods mainly focused on the prediction of phosphorylation sites, but rare methods considered whether a phosphorylation site is functional or not. Since functional phosphorylation sites are more valuable for further experimental research and a proportion of phosphorylation sites have no direct functional effects, the prediction of functional phosphorylation sites is quite necessary for this research area. Previous studies have shown that functional phosphorylation sites are more conserved than non-functional phosphorylation sites in evolution. Thus, in our method, we developed a web server by integrating existing phosphorylation site prediction methods, as well as both absolute and relative evolutionary conservation scores to predict the most likely functional phosphorylation sites. Using our method, we predicted the most likely functional sites of the human, rat and mouse proteomes and built a database for the predicted sites. By the analysis of overall prediction results, we demonstrated that protein phosphorylation plays an important role in all the enriched KEGG pathways. By the analysis of protein-specific prediction results, we demonstrated the usefulness of our method for individual protein studies. Our method would help to characterize the most likely functional phosphorylation sites for further studies in this research area.
\end{abstract}

KEYWORDS protein, phosphorylation, function, conser- vation, evolution

\section{INTRODUCTION}

Protein phosphorylation is a kind of post-translational modification and has been shown to be one of the most essential regulatory and signaling mechanisms in the cell (Zolnierowicz and Bollen, 2000). The process is catalyzed by protein kinases, in which the $y$ phosphate on ATP or GTP is transferred to the substrates. In eukaryotic cells, phosphorylation usually takes place on Serine (S), Threonine (T) or Tyrosine (Y) of the substrate protein. The phosphate on substrates can be removed by phosphatases, so the phosphorylation process is reversible: it is determined by the balance between the protein kinases and phosphatases. This reversible character allows the phosphorylation process to work like a switch in a living cell. Specific substrates could be activated by protein kinases under the simulation of an external signal. After the signal wanes, the activated substrates could be inactivated by phosphatases and wait for the next signal. Phosphorylation can regulate a variety of important protein functions, including subcellular localization, protein degradation and stabilization, as well as biochemical activities (Cohen, 2000; Ficarro et al., 2002; Manning et al., 2002a; Zannini et al., 2012). There are usually a series of phosphorylation processes involved in a normal biological function in vivo (Ubersax and Ferrell, 2007; Cai et al., 2012). It was also implicated in various pathological processes, such as cancer (Finn and Lu, 2008; Ollila and Makela, 2011, insulin resistance (Tanti and Jager, 2009), polyglutamine disease (Zhou et al., 2008) and Alzheimer's disease (Chung, 2009).

In an eukaryotic cell, about $30 \%-50 \%$ of the proteins can be phosphorylated (Pinna and Ruzzene, 1996). There are

\footnotetext{
*These authors contributed equally to the work.
} 
also hundreds of kinases within an eukaryotic genome, for instances: 518 protein kinases in humans (Manning et al., 2002b), 540 kinases in mice (Caenepeel et al., 2004) and 251 kinases in Drosophila (Morrison et al., 2000). The enzymes must be specific and act only on a defined subset of cellular targets to ensure signal fidelity. Cells must have a mechanism to control the phosphorylation process involving so many kinases and protein substrates simultaneously and precisely. This mechanism is mainly realized by the specific recognization of protein kinases to substrates, which determines the exact time and place for phosphorylation to occur. Thus, the identification of the involved kinases and their phosphorylation sites is the first step to understand the mechanism.

Currently there are a number of computational methods for phosphorylation site prediction. Generally, these methods can be divided into two categories: non-kinase-specific and kinase-specific phosphorylation site prediction. For non- kinase-specific phosphorylation site prediction, there exist NetPhos (Blom et al., 1999), DISPHOS (lakoucheva et al., 2004), PHOSIDA (Gnad et al., 2007), etc.. For kinase-specific phosphorylation site prediction, there exist GPS (Xue et al., 2010), NetPhosK (Blom et al., 2004), KinasePhos (Wong et al., 2007), PPSP (Xue et al., 2006), etc.. Although these methods could predict whether S/Y/T sites could be phosphorylated or not, they cannot predict whether a phosphorylation site is functional or not, which is a major issue for further experimental researches.

For the phosphorylation sites with known functions, it had been demonstrated that they are under strong functional constraints and are evolutionarily more conserved than those with no characterized functions (Landry et al., 2009; Ba and Moses, 2010). So the evolutionary information of $S / Y / T$ sites can be incorporated to identify the most likely functional phosphorylation sites. Since most phosphosites occur in disordered regions and the conservation of phosphorylation sites is also influenced by the region in which the residue is located (Landry et al., 2009), it is necessary to consider the relative conservation of an $S / Y / T$ site against its flanking region. Based on these considerations, we developed a prediction method that incorporated both absolute and relative conservation information of $S / Y / T$ sites to facilitate the identification of the most likely functional phosphorylation sites.

\section{RESULTS}

\section{Web server development}

We developed a web server, which incorporated NetPhos (Blom et al., 1999) and NetPhosK (Blom et al., 2004) to predict general and kinase-specific phosphorylation sites. Users can also upload prediction results from other phosphorylation site prediction tools as a formatted table (the table template can be downloaded from the web server). PhosphoSitePlus (Hornbeck et al., 2012) was incorporated to mark whether a predicted phosphorylation site is experimentally validated or not. Then, the server calculated the absolute and relative conservation score for each possible phosphorylation site with Rate4site. Both scores were normalized to the range of $0-1$, and the larger the relative and absolute conservation score is, the more likely the phosphorylation site is functional. The access of the web server is "http://lifecenter.sgst.cn/ppps/en/ home.do". Using the web server, users could predict most likely functional phosphorylation sites using UniProt ID, the query box is shown as Fig. 1, and the query result is shown as Fig. 2. The web server could also search the predicted results in the constructed human, rat and mouse database and the query box is shown as Fig. 3. Users could also search the database by a specific kinase and the query box is shown as Fig. 4 .

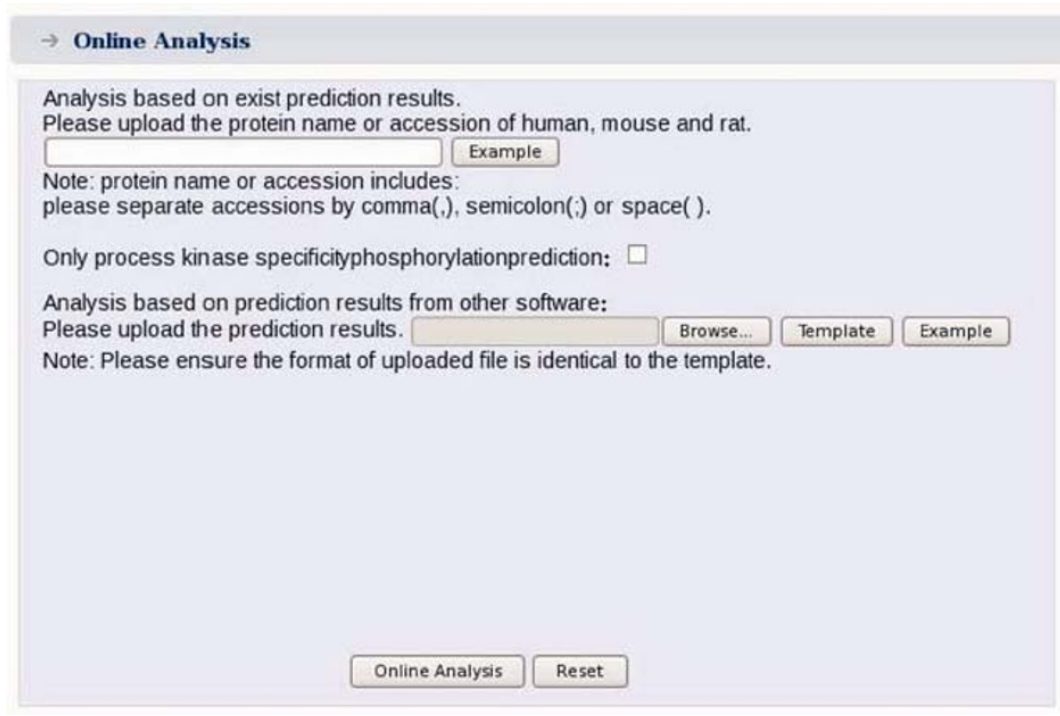

Figure 1. The search box for prediction of more likely functional phosphorylation sites by UniProt IDs 


\section{Detail}

Q9vSA3

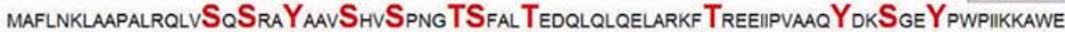

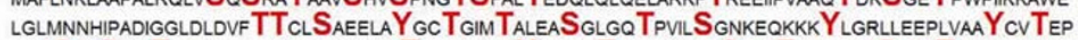
GagSoVS GIKTRAEKKGDEWVINGQKMWIT NGGVANWYFVLART NPDPKCPPSKAFTGFIVERDSPGLTPGRKELNMGQR

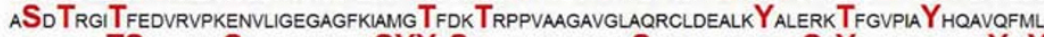

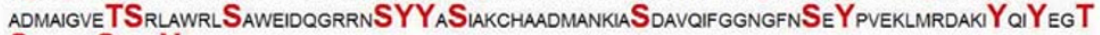
SoIQRLIISRMMYEAKGOA

\begin{tabular}{|c|c|c|c|c|c|}
\hline Position & $\begin{array}{l}\text { Site } \\
\uparrow \downarrow\end{array}$ & $\begin{array}{l}\text { RCS } \\
+4\end{array}$ & $\begin{array}{l}\text { ACS } \\
+4\end{array}$ & Valldated & Soft Kinase Context Score \\
\hline 104 & s & 0.70047 & 0.53121 & no & Netphos unsp TTCLSAEEL 0.972 \\
\hline 243 & T & 0.75236 & 0.81559 & no & Netphos unsp RASDTRGIT 0.52 \\
\hline 38 & $T$ & 0.84625 & 0.71257 & no & Netphos unsp SFALTEDQL 0.565 \\
\hline 328 & T & 0.59678 & 0.55867 & no & Netphos unsp IGVETSRLA 0.971 \\
\hline 228 & $T$ & 0.37069 & 0.55389 & no & Netphos unsp SPGLTPGRK 0.88 \\
\hline 336 & s & 0.73717 & 0.57358 & no & Netphos unsp AWRLSAWEI 0.844 \\
\hline 29 & s & 0.82282 & 0.18081 & no & Netphos unsp VSHVSPNGT 0.924 \\
\hline 241 & s & 0.72039 & 0.81935 & no & Netphos unsp GQRASDTRG 0.986 \\
\hline 127 & $T$ & 0.67276 & 0.55033 & no & Netphos unsp GLGQTPVIL 0.668 \\
\hline 347 & s & 0.74138 & 0.72063 & no & Netphos unsp GRRNSYYAS 0.994 \\
\hline
\end{tabular}

$$
\begin{array}{|l|l|l|l|l|l|l|l|l|l|l|l|l|}
\hline 58 & 1 / 6 & 1 & 2 & 3 & 4 & 5 & 6 & \gg> & 10 & \cdot
\end{array}
$$

Figure 2. The prediction results of the web server.

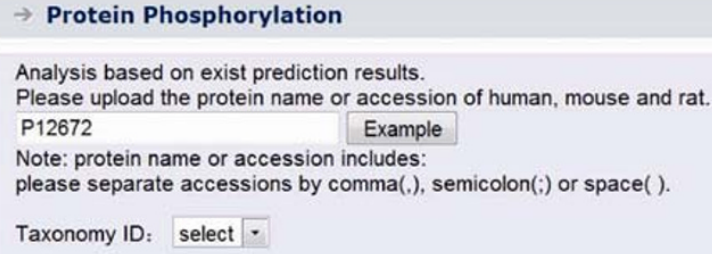

Figure 3. Search in the constructed human, rat and mouse database.

\section{$\rightarrow$ Kinase}

Browse kinases by their first names(not case senstive):

A, B, C, D, E, F, G, H, I, J, K, L, M, N,

$\mathrm{O}, \mathrm{P}, \mathrm{Q}, \mathrm{R}, \mathrm{S}, \mathrm{T}, \mathrm{U}, \mathrm{V}, \mathrm{W}, \mathrm{X}, \mathrm{Y}, \mathrm{Z}$

Or Input kinase name:

Figure 4. Kinase-specific search in the constructed human, rat and mouse database. 


\section{Human, rat and mouse database construction}

We selected the phosphorylation sites predicted by both NetPhos and GPS (Xue et al., 2010), and the conservation scores could be calculated to construct the human, rat and mouse database. For human, rat and mouse proteome, the number of the phosphorylation sites predicted by NetPhos, GPS or both, and the statistics of the final database are shown in Table 1. The "Database sites" column indicates the selected predicted phosphorylation sites in the database. The "Protein sequences" column indicates the number of protein sequences containing the selected predicted phosphorylation sites in the database. The "Experimentally validated sites" column indicates the number of experimentally validated phosphorylation sites in the database.

\section{Analysis of relative and absolute conservation scores of human, rat and mouse database}

We compared the density distribution of the relative and absolute conservation score of human, rat and mouse database using $R$ stats package (Fig. 5). The density distribution of the relative conservation score of human, rat and mouse are consistent, the density distribution of the absolute conservation score are also consistent. For both relative and absolute conservation score density distribution, there are two peaks: one at about 0.025 and one at about 0.80 . So our method not only can predict which phosphorylation sites are most likely to be functional, but also can give clues to which phosphorylation sites are least likely to be functional, thus can help relevant researchers to select more conserved and important phosphorylation sites to perform further studies. The density distribution of the relative and absolute conservation score intersect at about 0.85 . For conservation score larger than 0.85 , the distribution density of the relative conservation score is larger than the absolute conservation score. It may be explained that some phosphorylation sites are more conserved against its flanking region than against the overall protein sequence. For the majority of conservation score less than 0.85 , the distribution density of the absolute conservation score is larger than the relative conservation score, indicating that some phosphorylation sites are less conserved

Table 1 Statistics of the constructed human, rat and mouse database

\begin{tabular}{lllllll}
\hline & NetPhos predicted sites & $\begin{array}{l}\text { GPS predicted } \\
\text { sites }\end{array}$ & Both predicted sites & $\begin{array}{l}\text { Database } \\
\text { sites }\end{array}$ & Protein sequences & $\begin{array}{l}\text { Experimentally } \\
\text { validated sites }\end{array}$ \\
\hline Human & 657160 & 1774630 & 650289 & 551104 & 17771 & 28339 \\
Rat & 826362 & 2227169 & 816504 & 282438 & 12726 & 1064 \\
Mouse & 1064226 & 2885697 & 1053162 & 355280 & 14715 & 7938 \\
\hline
\end{tabular}

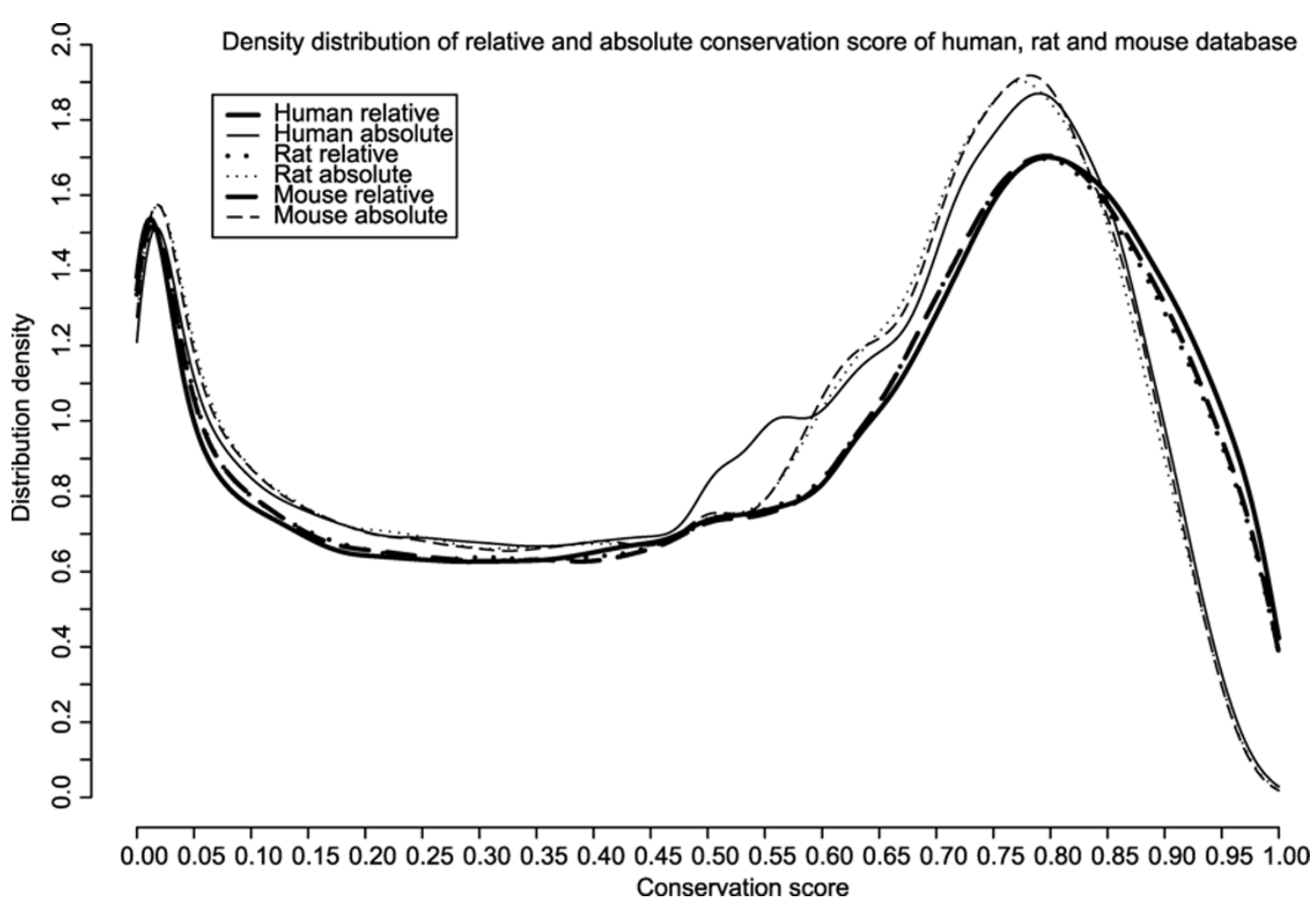

Figure 5. The density distribution of the relative and absolute conservation score of human, rat and mouse database. 
against their flanking region than against the overall protein sequence. Previous studies showed that the conservation of phosphorylation sites is also influenced by the region in which the residue is located (Landry et al., 2009), the density distribution of the absolute and relative conservation score also demonstrated that it is necessary to consider both the relative and absolute conservation of an $S / Y / T$ site against its flanking region and the overall protein sequence, respectively.

\section{General prediction results}

We used the selected proteins as mentioned in the Materials and methods section to do the KEGG pathway enrichment analysis. The results for human, rat and mouse are shown in Table 2, Table 3 and Table 4, respectively. We found that the functions of protein phosphorylation in all the enriched KEGG pathways are supported by previous studies.

Table 2 Enriched KEGG pathways for selected human proteins

\begin{tabular}{|c|c|c|c|}
\hline $\begin{array}{l}\text { KEGG } \\
\text { ID }\end{array}$ & $P$ value & KEGG Term & References \\
\hline 04110 & 0.000 & Cell cycle & $\begin{array}{l}\text { Bradbury et al., 1974; Lee et al., 1988; Atherton-Fessler et al., 1993; Lew and Kornbluth, 1996; Ma- } \\
\text { tsuoka et al., 1998; Konishi et al., 2002; Yu and Chen, } 2004\end{array}$ \\
\hline 05215 & 0.000 & Prostate cancer & $\begin{array}{l}\text { Haldar et al., 1996; Lin et al., 2002; El Sheikh et al., 2004; Jiang et al., 2004; Kreisberg et al., 2004; } \\
\text { Jaggi et al., 2005; Chen et al., 2006; Shimada et al., 2006; Mahajan et al., 2007; Bianchini et al., } 2008\end{array}$ \\
\hline 04520 & 0.000 & Adherens junction & $\begin{array}{l}\text { Volberg et al., 1992; Collares-Buzato et al., 1998; Andriopoulou et al., 1999; Gomez et al., 1999; Tins- } \\
\text { ley et al., 1999; Serres et al., 2000; Shasby et al., } 2002\end{array}$ \\
\hline 04910 & 0.000 & $\begin{array}{l}\text { Insulin } \\
\text { signaling pathway }\end{array}$ & $\begin{array}{l}\text { Myers et al., 1998; Zick, 2001; Aguirre et al., 2002; Andreozzi et al., 2004; Ueki et al., 2004; Gual et al., } \\
\text { 2005; McManus et al., 2005; Ueno et al., 2005; D'Alessandris et al., 2007; Wang et al., } 2007\end{array}$ \\
\hline 03013 & 0.000 & RNA transport & Aubol et al., 2004; Topisirovic et al., 2004 \\
\hline 03040 & 0.000 & Spliceosome & Mermoud et al., 1994; Wang et al., 1999; Mathew et al., 2008 \\
\hline 05200 & 0.000 & Pathways in cancer & $\begin{array}{l}\text { Foster and Wimalasena, 1996; Itoh et al., 2002; Viglietto et al., 2002; Vivanco and Sawyers, 2002; } \\
\text { Altomare et al., 2004; Viatour et al., 2005; Cicenas, } 2008\end{array}$ \\
\hline 05213 & 0.000 & Endometrial cancer & Kleinman et al., 1996; Kanamori et al., 2001; Terakawa et al., 2003 \\
\hline 05220 & 0.000 & $\begin{array}{l}\text { Chronic } \\
\text { myeloid leukemia }\end{array}$ & Oda et al., 1996; Coluccia et al., 2007; Jilani et al., 2008; Jalkanen et al., 2011; Zhang et al., 2012 \\
\hline 04810 & 0.000 & $\begin{array}{l}\text { Regulation of } \\
\text { actin cytoskeleton }\end{array}$ & Arber et al., 1998; Sumi et al., 1999; Head et al., 2003; Vardouli et al., 2005; Park et al., 2012 \\
\hline 04114 & 0.000 & Oocyte meiosis & Dekel, 1996; Fan et al., 2002; Wang et al., 2006a; Liang et al., 2007; Swain and Smith, 2007 \\
\hline 05223 & 0.000 & $\begin{array}{l}\text { Non-small cell } \\
\text { lung cancer }\end{array}$ & Lee et al., 2002; Cappuzzo et al., 2004; Kim et al., 2005; Tang et al., 2006; Tsurutani et al., 2006 \\
\hline 04012 & 0.000 & $\begin{array}{l}\text { ErbB } \\
\text { signaling pathway }\end{array}$ & Sweeney and Carraway, 2000; El Sheikh et al., 2004; Fan et al., 2005; Schmidt et al., 2011 \\
\hline 04530 & 0.000 & Tight junction & $\begin{array}{l}\text { Nigam et al., 1991; Collares-Buzato et al., 1998; Shen et al., 2006; Wang et al., 2006b; Aono and Hirai, } \\
\text { 2008; Rao, 2009; Sallee and Burridge, } 2009\end{array}$ \\
\hline 04144 & 0.000 & Endocytosis & $\begin{array}{l}\text { Slepnev et al., 1998; Nucifora and Fox, 1999; Cousin et al., 2001; Whistler et al., 2001; Schaefer et al., } \\
\text { 2002; Collawn, 2006; Zhu et al., 2007; Clayton et al., } 2010\end{array}$ \\
\hline 05214 & 0.000 & Glioma & $\begin{array}{l}\text { Oude Weernink et al., 1996; Nakada et al., 2004; Bornhauser and Lindholm, 2005; McDonough et al., } \\
\text { 2005; van der Horst et al., 2005; Nakada et al., 2010; Feng et al., } 2011\end{array}$ \\
\hline 04120 & 0.000 & $\begin{array}{l}\text { Ubiquitin mediated } \\
\text { proteolysis }\end{array}$ & $\begin{array}{l}\text { Willems et al., 1996; Skowyra et al., 1997; Willems et al., 1999; Karin and Ben-Neriah, 2000; Koepp et } \\
\text { al., 2001; Busino et al., } 2004\end{array}$ \\
\hline 04914 & 0.000 & $\begin{array}{l}\text { Progesterone-mediated } \\
\text { oocyte maturation }\end{array}$ & Mulner et al., 1985; Muslin et al., 1993; Nebreda et al., 1995; Ju et al., 2002 \\
\hline 05212 & 0.000 & Pancreatic cancer & $\begin{array}{l}\text { Ng et al., 2001; Adachi et al., 2010; Deming et al., 2010; Nakashima et al., 2011; Vo et al., 2011; Zheng } \\
\text { et al., 2011; Ma et al., } 2012\end{array}$ \\
\hline 04270 & 0.000 & $\begin{array}{l}\text { Vascular smooth } \\
\text { muscle contraction }\end{array}$ & $\begin{array}{l}\text { Walker et al., 1994; Zhang et al., 1994; Hirano et al., 2004; Kordowska et al., 2006; Anfinogenova et } \\
\text { al., } 2007\end{array}$ \\
\hline 05219 & 0.000 & Bladder cancer & $\begin{array}{l}\text { Yamamoto et al., 2006; Miyata et al., 2009; Szanto et al., 2009; Wang et al., 2010; Khadjavi et al., } \\
\text { 2011; Ou et al., } 2011\end{array}$ \\
\hline 04010 & 0.000 & $\begin{array}{l}\text { MAPK } \\
\text { signaling pathway }\end{array}$ & $\begin{array}{l}\text { Aubin et al., 2004; Mylonis et al., 2006; Carriere et al., 2008; Junttila et al., 2008; Matsumoto et al., } \\
\text { 2008; Kim et al., 2011; Li et al., } 2011\end{array}$ \\
\hline 04510 & 0.000 & Focal adhesion & $\begin{array}{l}\text { Kornberg et al., 1992; Calalb et al., 1995; Chen et al., 1996; Slack, 1998; Tang et al., 1999; Brunton et } \\
\text { al., 2005; Mimura et al., } 2005\end{array}$ \\
\hline 04720 & 0.000 & $\begin{array}{l}\text { Long-term } \\
\text { potentiation }\end{array}$ & $\begin{array}{l}\text { Atkins et al., 1997; Barria et al., 1997; Fujii et al., 2000; Manabe et al., 2000; Lonart et al., 2003; } \\
\text { Serrano et al., 2005; Bouzioukh et al., 2007; Capron et al., 2007; Schafe et al., } 2008\end{array}$ \\
\hline 04150 & 0.000 & $\begin{array}{l}\text { mTOR } \\
\text { signaling pathway }\end{array}$ & $\begin{array}{l}\text { Altomare et al., 2004; Acosta-Jaquez et al., 2009; Copp et al., 2009; Kruck et al., 2010; Rosner et al., } \\
\text { 2010; Dai et al., 2011 }\end{array}$ \\
\hline
\end{tabular}


Table 3 Enriched KEGG pathways for selected rat proteins

\begin{tabular}{|c|c|c|c|}
\hline $\begin{array}{l}\text { KEGG } \\
\text { ID }\end{array}$ & $P$ value & Term & References \\
\hline 04722 & 0.000 & $\begin{array}{l}\text { Neurotrophin signaling } \\
\text { pathway }\end{array}$ & $\begin{array}{l}\text { Mutoh et al., 2000; Wang et al., 2000; Viegi et al., 2002; Arevolo et al., 2006; Butowt and von } \\
\text { Bartheld, 2009; Zhang et al., } 2009\end{array}$ \\
\hline 04910 & 0.000 & $\begin{array}{l}\text { Insulin signaling } \\
\text { pathway }\end{array}$ & $\begin{array}{l}\text { Myers et al., 1998; Zick, 2001; Aguirre et al., 2002; Andreozzi et al., 2004; Ueki et al., 2004; Gual et } \\
\text { al., 2005; McManus et al., 2005; Ueno et al., 2005; D'Alessandris et al., 2007; Wang et al., } 2007\end{array}$ \\
\hline 04720 & 0.000 & Long-term potentiation & $\begin{array}{l}\text { Atkins et al., 1997; Barria et al., 1997; Fujii et al., 2000; Manabe et al., 2000; Lonart et al., 2003; } \\
\text { Serrano et al., 2005; Bouzioukh et al., 2007; Capron et al., 2007; Schafe et al., } 2008\end{array}$ \\
\hline 04012 & 0.000 & ErbB signaling pathway & Sweeney and Carraway, 2000; El Sheikh et al., 2004; Fan et al., 2005; Schmidt et al., 2011 \\
\hline 05214 & 0.000 & Glioma & $\begin{array}{l}\text { Oude Weernink et al., 1996; Nakada et al., 2004; Bornhauser and Lindholm, 2005; McDonough et } \\
\text { al., 2005; van der Horst et al., 2005; Nakada et al., 2010; Feng et al., } 2011\end{array}$ \\
\hline 04810 & 0.000 & $\begin{array}{l}\text { Regulation of actin } \\
\text { cytoskeleton }\end{array}$ & Arber et al., 1998; Sumi et al., 1999; Head et al., 2003; Vardouli et al., 2005; Park et al., 2012 \\
\hline 04270 & 0.001 & $\begin{array}{l}\text { Vascular smooth } \\
\text { muscle contraction }\end{array}$ & $\begin{array}{l}\text { Walker et al., 1994; Zhang et al., 1994; Hirano et al., 2004; Kordowska et al., 2006; Anfinogenova et } \\
\text { al., } 2007\end{array}$ \\
\hline 05223 & 0.001 & $\begin{array}{l}\text { Non-small cell lung } \\
\text { cancer }\end{array}$ & Lee et al., 2002; Cappuzzo et al., 2004; Kim et al., 2005; Tang et al., 2006; Tsurutani et al., 2006 \\
\hline
\end{tabular}

Table 4 Enriched KEGG pathways for selected mouse proteins

\begin{tabular}{|c|c|c|c|}
\hline $\begin{array}{l}\text { KEGG } \\
\text { ID }\end{array}$ & $P$ value & Term & References \\
\hline 04530 & 0.000 & Tight junction & $\begin{array}{l}\text { Nigam et al., 1991; Collares-Buzato et al., 1998; Shen et al., 2006; Wang et al., 2006b; Aono and } \\
\text { Hirai, 2008; Rao, 2009; Sallee and Burridge, 2009 }\end{array}$ \\
\hline 04510 & 0.000 & Focal adhesion & $\begin{array}{l}\text { Kornberg et al., 1992; Calalb et al., 1995; Chen et al., 1996; Slack, 1998; Tang et al., 1999; Brunton } \\
\text { et al., 2005; Mimura et al., } 2005\end{array}$ \\
\hline 04012 & 0.000 & ErbB signaling pathway & Sweeney and Carraway, 2000; El Sheikh et al., 2004; Fan et al., 2005; Schmidt et al., 2011 \\
\hline 04670 & 0.000 & $\begin{array}{l}\text { Leukocyte transendothe- } \\
\text { lial migration }\end{array}$ & $\begin{array}{l}\text { Alevriadou, 2003; Allingham et al., 2007; Barberis et al., 2009; Muller, 2009; Fernandez-Borja et al., } \\
2010\end{array}$ \\
\hline 04520 & 0.000 & Adherens junction & $\begin{array}{l}\text { Volberg et al., 1992; Collares-Buzato et al., 1998; Andriopoulou et al., 1999; Gomez et al., 1999; } \\
\text { Tinsley et al., 1999; Serres et al., 2000; Shasby et al., } 2002\end{array}$ \\
\hline 04910 & 0.000 & Insulin signaling pathway & $\begin{array}{l}\text { Myers et al., 1998; Zick, 2001; Aguirre et al., 2002; Andreozzi et al., 2004; Ueki et al., 2004; Gual et } \\
\text { al., 2005; McManus et al., 2005; Ueno et al., 2005; D'Alessandris et al., 2007; Wang et al., } 2007\end{array}$ \\
\hline 04810 & 0.000 & $\begin{array}{l}\text { Regulation of actin } \\
\text { cytoskeleton }\end{array}$ & Arber et al., 1998; Sumi et al., 1999; Head et al., 2003; Vardouli et al., 2005; Park et al., 2012 \\
\hline 05213 & 0.001 & Endometrial cancer & Kleinman et al., 1996; Kanamori et al., 2001; Terakawa et al., 2003 \\
\hline
\end{tabular}

\section{Enrichment analysis for human}

For the human proteome, we selected a total of 1755 proteins containing 2834 predicted phosphorylation sites (the selection criteria of top $10 \%$ is 0.918232 ). We matched the 1755 selected UniProt protein IDs to their gene ids using the $R$ package org.Hs.eg.db and used all the gene ids in the org.Hs.egUNIPROT table within this $\mathrm{R}$ package as the background. The cutoff of the $P$ value in the enrichment analysis was set to 0.001 . There are 25 enriched KEGG pathways (Table 2), in all of which protein phosphorylation has been demonstrated to play important roles, as shown in the References column of Table 2 .

\section{Enrichment analysis for rat}

For the rat proteome, we selected a total of 85 protein sequences containing 107 predicted phosphorylation sites (the selection criteria of top $10 \%$ is 0.923121 ). We matched the 85 selected UniProt protein IDs to their gene ids using the $R$ package org.Rn.eg.db and used all the gene ids in the org.Rn.egUNIPROT table within this $\mathrm{R}$ package as the background. The cutoff of the $P$ value in the analysis was set to 0.001 . There are 8 enriched KEGG pathways (listed in Table 3) for the selected rat proteins. The important roles of protein phosphorylation in all of these KEGG pathways had been supported by previous studies.

\section{Enrichment analysis for mouse}

For the mouse proteome, we selected a total of 555 protein sequences containing 794 predicted phosphorylation sites (the selection criteria of top $10 \%$ is 0.917137 ). We matched the 555 selected UniProt protein IDs to their gene ids using the $\mathrm{R}$ package org.Mm.eg.db and used all the gene ids in the org.Mm.egUNIPROT table within this $\mathrm{R}$ package as the background. The cutoff of the $P$ value in the analysis was set to 0.001 . There are 8 enriched KEGG pathways (Table 4 ) for the selected mouse proteins. The important roles of protein phosphorylation in all of these enriched KEGG pathways 
have been supported by previous studies.

\section{Protein specific prediction results}

We used two well-studied proteins, p53 and Cyclin-dependent kinase inhibitor $1 \mathrm{~B}$, in which phosphorylation plays an important role, to demonstrate the usefulness of our method for individual protein phosphorylation studies.

\section{p53}

Our method totally predicted 23 phosphorylation sites in p53 (Table 5). We ranked the predicted phosphorylation sites by their relative conservation scores. Within these 23 sites, 14 sites have been experimentally validated to be phosphorylated. And according to the annotation of UniProt (Version 196), 9 phosphorylation sites have been supported to be functional. Our method predicted 5 of these 9 functional phosphorylation sites (site 15, 46, 392, 315 and 9). The ranks of the relative conservation score of these 5 sites were 2, 3, 5, 6 and 19, respectively. p53 serine 15 phosphorylation could direct its interaction with B56y and the tumor suppressor activity of B56y-specific protein phosphatase 2A (Shouse et al., 2008). p53 serine 46 could be phosphorylated by HIPK2 upon UV irradiation, which could regulate p53 apoptotic activity and is required for acetylation by CREBBP (D'Orazi et al., 2002; Hofmann et al., 2002; Chang et al., 2005; Lee et al., 2009). Phosphorylation at serine 9 by HIPK4 could increase the repression activity of p53 at p53 repressive promoters (Arai et al., 2007). Phosphorylation of serine 392 stabilizes the tetramer formation of tumor suppressor protein p53 and could stimulate the DNA-binding ability of p53 (Sakaguchi et al., 1997; Kapoor et al., 2000). Phosphorylation of p53 at serine 315 after irradiation damage could stimulate p53-dependent transcription (Blaydes et al., 2001).

We can see that 4 of these 5 sites were within the top 6 sites ranked by the relative conservation score. For site 9 , it may be explained that the function of site 9 phosphorylation is relatively less important for biological activities and a previous study has demonstrated that the specific recognition of Ser9 appears to be dependent upon additional determinants of p53 beyond the $\mathrm{N}$-terminal 65 amino acids (Soubeyrand et al., 2004). But for site 9 , we can also find that the relative conservation score $(0.3185200)$ is much larger than the absolute conservation score $(0.1658500)$, indicating it is more conserved against its flanking region than against the overall protein sequence.

Table 5 Predicted p53 phosphorylation sites

\begin{tabular}{|c|c|c|c|c|c|c|}
\hline Rank & Sequence & Site & Residue & Validated & Absolute conservation score & Relative conservation score \\
\hline 1 & P04637 & 303 & $S$ & no & 0.6791800 & 0.8640700 \\
\hline 2 & P04637 & 15 & $\mathbf{S}$ & yes & 0.7778000 & 0.8542900 \\
\hline 3 & P04637 & 46 & $\mathbf{S}$ & yes & 0.5023500 & 0.8389500 \\
\hline 4 & P04637 & 211 & $\mathrm{~T}$ & no & 0.8468500 & 0.8309000 \\
\hline 5 & P04637 & 392 & $\mathbf{S}$ & yes & 0.8517600 & 0.8048300 \\
\hline 6 & P04637 & 315 & $\mathbf{S}$ & yes & 0.6791800 & 0.7976600 \\
\hline 7 & P04637 & 284 & $\mathrm{~T}$ & no & 0.8468500 & 0.7892800 \\
\hline 8 & P04637 & 215 & $S$ & yes & 0.8517600 & 0.7698900 \\
\hline 9 & P04637 & 121 & $S$ & no & 0.8517600 & 0.7693900 \\
\hline 10 & P04637 & 269 & $S$ & no & 0.8517600 & 0.7678400 \\
\hline 11 & P04637 & 366 & $S$ & yes & 0.5387800 & 0.6999100 \\
\hline 12 & P04637 & 376 & $S$ & yes & 0.4991900 & 0.6883600 \\
\hline 13 & P04637 & 163 & $Y$ & no & 0.7719500 & 0.6545700 \\
\hline 14 & P04637 & 183 & $S$ & no & 0.6474700 & 0.4546000 \\
\hline 15 & P04637 & 99 & $S$ & yes & 0.4991900 & 0.4506600 \\
\hline 16 & P04637 & 155 & $T$ & yes & 0.4119200 & 0.3710500 \\
\hline 17 & P04637 & 9 & $\mathbf{S}$ & yes & 0.1658500 & 0.3185200 \\
\hline 18 & P04637 & 260 & $S$ & no & 0.5472000 & 0.3151700 \\
\hline 19 & P04637 & 304 & $\mathrm{~T}$ & no & 0.2678600 & 0.2932800 \\
\hline 20 & P04637 & 371 & $S$ & yes & 0.1512700 & 0.1801200 \\
\hline 21 & P04637 & 377 & $\mathrm{~T}$ & yes & 0.2521900 & 0.1721600 \\
\hline 22 & P04637 & 150 & $\mathrm{~T}$ & yes & 0.0648860 & 0.0831870 \\
\hline 23 & P04637 & 81 & $\mathrm{~T}$ & yes & 0.0071032 & 0.0081448 \\
\hline
\end{tabular}




\section{Cyclin-dependent kinase inhibitor 1B}

For cyclin-dependent kinase inhibitor 1B, our method predicted totally 19 phosphorylation sites (Table 6), within which 10 sites have been experimentally validated. According to the annotation of UniProt (Version 138), a total of 5 phosphorylation sites have been supported to be functional. Our method predicted 3 of these 5 functional phosphorylation sites, i.e. site 187, 10 and 198. The rank of the relative conservation score of these 3 sites were 2, 6 and 12, respectively. Phosphorylation of threonine 187 leads to protein ubiquitination and proteasomal degradation (Boehm et al., 2002; Fujita et al., 2002; Motti et al., 2004; Hao et al., 2005; Sabile et al., 2006). Phosphorylation of serine 10 is the major site of phosphorylation in resting cells, which takes place at the $\mathrm{G}(0)-\mathrm{G} 1$ phase and leads to protein stability (Boehm et al., 2002; Fujita et al., 2002; Motti et al., 2004). Phosphorylation of threonine 198 is required for interaction with 14-3-3 proteins (Fujita et al., 2002, 2003; Motti et al., 2004). The relative conservation scores of all these three sites were larger than 0.7 . The high relative conservation score of other sites may be explained by the possibility that the function of these sites may not have been studies or these sites may not work by phosphorylation directly. However there were also 6 predicted phosphorylation sites with relative conservation scores less than 0.2. It may give further studies a clue that researchers could pay less attention to these sites than those having higher conservation scores.

\section{DISCUSSION}

In this work, a prediction web server was developed to facilitate the identification of the most likely functional protein phosphorylation sites by incorporating both the absolute and relative evolutionary conservation scores. The larger the relative and absolute conservation score is, the more likely the phosphorylation sites is functional. To facilitate the usage of our method, we also selected and integrated two existing computational methods: NetPhos and NetPhosK for general and kinase-specific phosphorylation site prediction, respectively. Using our method, we predicted the most likely functional sites of the human, rat and mouse proteomes and built a database for the predicted phosphorylation sites. By the analysis of overall prediction results, we demonstrated that protein phosphorylation plays an important role in all the enriched KEGG pathways. By the analysis of protein-specific prediction results, we also demonstrated the usefulness of our method for individual protein studies. Our method would help to characterize the most likely functional phosphorylation sites for further studies in this research area.

\section{MATERIALS AND METHODS}

\section{Web server development}

In our pipeline, we first predicted all possible phosphorylation sites for a protein with NetPhos (Blom et al., 1999) and NetPhosK (Blom et al.,

Table 6 Cyclin-dependent kinase inhibitor 1B predicted phosphorylation sites

\begin{tabular}{|c|c|c|c|c|c|c|}
\hline Rank & Sequence & Site & Residue & Validated & Absolute conservation score & Relative conservation score \\
\hline 1 & P46527 & 83 & S & yes & 0.91213 & 0.9451900 \\
\hline 2 & P46527 & 187 & $\mathbf{T}$ & yes & 0.89140 & 0.9250400 \\
\hline 3 & P46527 & 74 & Y & yes & 0.80464 & 0.8947000 \\
\hline 4 & P46527 & 161 & $S$ & no & 0.91181 & 0.8888900 \\
\hline 5 & P46527 & 178 & S & yes & 0.42948 & 0.8449600 \\
\hline 6 & P46527 & 10 & $\mathbf{S}$ & yes & 0.91213 & 0.8214100 \\
\hline 7 & P46527 & 110 & S & no & 0.71083 & 0.8168600 \\
\hline 8 & P46527 & 175 & S & no & 0.38966 & 0.7975000 \\
\hline 9 & P46527 & 27 & $S$ & no & 0.91213 & 0.7801300 \\
\hline 10 & P46527 & 7 & $S$ & yes & 0.91213 & 0.7548800 \\
\hline 11 & P46527 & 160 & $S$ & no & 0.74949 & 0.7440600 \\
\hline 12 & P46527 & 198 & $\mathbf{T}$ & yes & 0.42011 & 0.7163300 \\
\hline 13 & P46527 & 140 & $S$ & yes & 0.46412 & 0.7131600 \\
\hline 14 & P46527 & 138 & $S$ & no & 0.10456 & 0.1775700 \\
\hline 15 & P46527 & 128 & $\mathrm{~T}$ & no & 0.21473 & 0.1357200 \\
\hline 16 & P46527 & 183 & $S$ & no & 0.12140 & 0.1085000 \\
\hline 17 & P46527 & 157 & $\mathrm{~T}$ & yes & 0.04299 & 0.0915960 \\
\hline 18 & P46527 & 42 & $\mathrm{~T}$ & no & 0.31554 & 0.0580880 \\
\hline 19 & P46527 & 12 & $S$ & yes & 0.37267 & 0.0068863 \\
\hline
\end{tabular}


2004), which are two existing computational methods for non-kinase-specific and kinase-specific prediction, respectively. The prediction results from other phosphorylation site prediction methods can also be provided as a formatted table (the table template can be downloaded from the web server). We incorporated PhosphoSitePlus (Hornbeck et al., 2012), which is a database containing experimentally validated phosphorylation sites, to mark whether a predicted phosphorylation site is experimentally validated or not.

For conservation score calculation, we used customized Rate4Site with default parameters (Pupko et al., 2002; Mayrose et al., 2004), which can compute the evolutionary rate for each site in a multiple sequence alignment. The alignments of ortholog families were downloaded from the NCBI HomoloGene database (Sayers et al., 2012). For the calculation of the absolute conservation score, we normalized the evolutionary rate $r$ of a phosphorylated site according to the rates of all the residues in the protein, i.e.

$$
z_{\text {abs }}=\frac{r-\mu\left(r_{\text {all }}\right)}{\sigma\left(r_{\text {all }}\right)}
$$

Where $\mu\left(r_{\text {all }}\right)$ and $\sigma\left(r_{\text {all }}\right)$ are the mean and standard deviation of the evolutionary rates of all residues. For the calculation of relative conservation score, we normalized $r$ according to the rates of the flanking residues around the phosphorylated site, 5 to the left and 5 to the right, i.e.

$$
z_{r e l}=\frac{r-\mu\left(r_{ \pm 5}\right)}{\sigma\left(r_{ \pm 5}\right)}
$$

We transformed the $z_{\text {abs }}$ and $z_{\text {rel }}$ scores to $[0,1]$ by using the probability function of the standard normal distribution.

\section{Human, rat and mouse database construction}

We downloaded the proteome sequences of human, rat and mouse from UniProt (Consortium, 2012). Using our method, we predicted the phosphorylation sites of these proteomes. To guarantee the prediction accuracy of our method, we took the phosphorylation sites predicted by both general and kinase-specific methods and having the conservation scores to construct the human, rat and mouse database. We then incorporated PhosphoSitePlus (Hornbeck et al., 2012) to mark whether the predicted sites have been experimentally validated or not.

\section{General and protein-specific prediction}

Since the function information of phosphorylation sites is limited, it is difficult to construct a benchmark dataset to test the overall prediction performance of our method. We ranked the predicted phosphorylation sites in the human, rat and mouse database according to the relative conservation score and selected the top $10 \%$ of the experimentally validated phosphorylation sites. Then we selected the protein sequences containing these top $10 \%$ sites and did KEGG enrichment of such proteins to find whether protein phosphorylation plays an important role in the enriched KEGG pathways.

We used two well-studied proteins, p53 and Cyclin-dependent kinase inhibitor $1 \mathrm{~B}$ in which phosphorylation plays an important role, to demonstrate the usage of our method for individual protein studies.

\section{ACKNOWLEDGEMENTS}

This work was supported by the National Basic Research Program (973 Program) (Nos. 2011CB910204, 2010CB529206 and 2010CB912702), Research Program of Chinese Academy of Sciences (Nos. KSCX2-EW-R-04, KSCX2-YW-R-190 and 2011KIP204), National Natural Science Foundation of China (Grant Nos. 30900272 and 31070752). Chinese Ministry for Science and Technology Grant (No. 2008BAl64B01) and the National High Technology Research and Development Program (863 Program) (No. 2009AA02Z304).

\section{REFERENCES}

Acosta-Jaquez, H.A., Keller, J.A., Foster, K.G., Ekim, B., Soliman, G.A., Feener, E.P., Ballif, B.A., and Fingar, D.C. (2009). Site-specific mTOR phosphorylation promotes mTORC1-mediated signaling and cell growth. Mol Cell Biol 29, 4308-4324.

Adachi, S., Yasuda, I., Nakashima, M., Yamauchi, T., Yamauchi, J., Natsume, H., Moriwaki, H., and Kozawa, O. (2010). HSP90 inhibitors induce desensitization of EGF receptor via p38 MAPK-mediated phosphorylation at Ser1046/1047 in human pancreatic cancer cells. Oncol Rep 23, 1709-1714.

Aguirre, V., Werner, E.D., Giraud, J., Lee, Y.H., Shoelson, S.E., and White, M.F. (2002). Phosphorylation of Ser307 in insulin receptor substrate-1 blocks interactions with the insulin receptor and inhibits insulin action. J Biol Chem 277, 1531-1537.

Alevriadou, B.R. (2003). CAMs and Rho small GTPases: gatekeepers for leukocyte transendothelial migration. Focus on "VCAM-1-mediated Rac signaling controls endothelial cell-cell contacts and leukocyte transmigration". Am J Physiol Cell Physiol 285, C250-252.

Allingham, M.J., van Buul, J.D., and Burridge, K. (2007). ICAM-1-mediated, Src- and Pyk2-dependent vascular endothelial cadherin tyrosine phosphorylation is required for leukocyte transendothelial migration. J Immunol 179, 4053-4064.

Altomare, D.A., Wang, H.Q., Skele, K.L., De Rienzo, A., Klein-Szanto, A.J., Godwin, A.K., and Testa, J.R. (2004). AKT and mTOR phosphorylation is frequently detected in ovarian cancer and can be targeted to disrupt ovarian tumor cell growth. Oncogene 23, 5853-5857.

Andreozzi, F., Laratta, E., Sciacqua, A., Perticone, F., and Sesti, G. (2004). Angiotensin II impairs the insulin signaling pathway promoting production of nitric oxide by inducing phosphorylation of insulin receptor substrate-1 on Ser312 and Ser616 in human umbilical vein endothelial cells. Circ Res 94, 1211-1218.

Andriopoulou, P., Navarro, P., Zanetti, A., Lampugnani, M.G., and Dejana, E. (1999). Histamine induces tyrosine phosphorylation of endothelial cell-to-cell adherens junctions. Arterioscl Throm Vas 19, 2286-2297.

Anfinogenova, Y., Wang, R.P., Li, Q.F., Spinelli, A.M., and Tang, D.D. (2007). Important role of Abelson tyrosine kinase (Abl) in regulating vascular smooth muscle contraction. Faseb $J$ 21, A1299-A1300.

Aono, S., and Hirai, Y. (2008). Phosphorylation of claudin-4 is required for tight junction formation in a human keratinocyte cell line. 
Exp Cell Res 314, 3326-3339.

Arai, S., Matsushita, A., Du, K., Yagi, K., Okazaki, Y., and Kurokawa, R. (2007). Novel homeodomain-interacting protein kinase family member, HIPK4, phosphorylates human p53 at serine 9. FEBS Lett 581, 5649-5657.

Arber, S., Barbayannis, F.A., Hanser, H., Schneider, C., Stanyon, C.A., Bernard, O., and Caroni, P. (1998). Regulation of actin dynamics through phosphorylation of cofilin by LIM-kinase. Nature 393, 805-809.

Arevolo, J.C., Pereira, D.B., Yano, H., Teng, K.K., and Chao, M.V. (2006). Identification of a switch in neurotrophin signaling by selective tyrosine phosphorylation. J Biol Chem 281, 1001-1007.

Atherton-Fessler, S., Hannig, G., and Piwnica-Worms, H. (1993). Reversible tyrosine phosphorylation and cell cycle control. Semin Cell Biol 4, 433-442.

Atkins, C.M., Chen, S.J., Klann, E., and Sweatt, J.D. (1997). Increased phosphorylation of myelin basic protein during hippocampal long-term potentiation. J Neurochem 68, 1960-1967.

Aubin, J., Davy, A., and Soriano, P. (2004). In vivo convergence of BMP and MAPK signaling pathways: impact of differential Smad1 phosphorylation on development and homeostasis. Gene Dev 18, 1482-1494.

Aubol, B.E., Ungs, L., Lukasiewicz, R., Ghosh, G., and Adams, J.A. (2004). Chemical clamping allows for efficient phosphorylation of the RNA carrier protein Npl3. J Biol Chem 279, 30182-30188.

Ba, A.N., and Moses, A.M. (2010). Evolution of characterized phosphorylation sites in budding yeast. Mol Biol Evol 27, 2027-2037.

Barberis, L., Pasquali, C., Bertschy-Meier, D., Cuccurullo, A., Costa, C., Ambrogi, C., Vilbois, F., Chiarle, R., Wymann, M., Altruda, F., et al. (2009). Leukocyte transmigration is modulated by chemokine-mediated PI3K gamma-dependent phosphorylation of vimentin. Eur J Immunol 39, 1136-1146.

Barria, A., Muller, D., Derkach, V., Griffith, L.C., and Soderling, T.R. (1997). Regulatory phosphorylation of AMPA-type glutamate receptors by CaM-KII during long-term potentiation. Science 276 , 2042-2045.

Bianchini, A., Loiarro, M., Bielli, P., Busa, R., Paronetto, M.P., Loreni, F., Geremia, R., and Sette, C. (2008). Phosphorylation of elF4E by MNKs supports protein synthesis, cell cycle progression and proliferation in prostate cancer cells. Carcinogenesis 29, 2279-2288.

Blaydes, J.P., Luciani, M.G., Pospisilova, S., Ball, H.M.L., Vojtesek, B., and Hupp, T.R. (2001). Stoichiometric phosphorylation of human p53 at Ser(315) stimulates p53-dependent transcription. J Biol Chem 276, 4699-4708.

Blom, N., Gammeltoft, S., and Brunak, S. (1999). Sequence and structure-based prediction of eukaryotic protein phosphorylation sites. J Mol Biol 294, 1351-1362.

Blom, N., Sicheritz-Ponten, T., Gupta, R., Gammeltoft, S., and Brunak, S. (2004). Prediction of post-translational glycosylation and phosphorylation of proteins from the amino acid sequence. Proteomics 4, 1633-1649.

Boehm, M., Yoshimoto, T., Crook, M.F., Nallamshetty, S., True, A., Nabel, G.J., and Nabel, E.G. (2002). A growth factor-dependent nuclear kinase phosphorylates p27(Kip1) and regulates cell cycle progression. EMBO J 21, 3390-3401.
Bornhauser, B.C., and Lindholm, D. (2005). MSAP enhances migration of C6 glioma cells through phosphorylation of the myosin regulatory light chain. Cell Mol Life Sci 62, 1260-1266.

Bouzioukh, F., Wilkinson, G.A., Adelmann, G., Frotscher, M., Stein, V., and Klein, R. (2007). Tyrosine phosphorylation sites in ephrinB2 are required for hippocampal long-term Potentiation but not long-term depression. J Neurosci 27, 11279-11288.

Bradbury, E.M., Inglis, R.J., and Matthews, H.R. (1974). Control of cell-division by very lysine rich histone (F1) phosphorylation. Nature 247, 257-261.

Brunton, V.G., Avizienyte, E., Fincham, V.J., Serrels, B., Metcalf, C.A., Sawyer, T.K., and Frame, M.C. (2005). Identification of Src-specific phosphorylation site on focal adhesion kinase: Dissection of the role of $\mathrm{Src} \mathrm{SH} 2$ and catalytic functions and their consequences for tumor cell behavior. Cancer Res 65, 1335-1342.

Busino, L., Chiesa, M., Draetta, G.F., and Donzelli, M. (2004). Cdc25A phosphatase: combinatorial phosphorylation, ubiquitylation and proteolysis. Oncogene 23, 2050-2056.

Butowt, R., and von Bartheld, C.S. (2009). Fates of neurotrophins after retrograde axonal transport: phosphorylation of p75NTR is a sorting signal for delayed degradation. J Neurosci 29, 10715-10729.

Caenepeel, S., Charydczak, G., Sudarsanam, S., Hunter, T., and Manning, G. (2004). The mouse kinome: Discovery and comparative genomics of all mouse protein kinases. Proc Natl Acad Sci U S A 101, 11707-11712.

Cai, N., Li, M., Qu, J., Liu, G.H., and Izpisua Belmonte, J.C. (2012). Post-translational modulation of pluripotency. J Mol Cell Biol. (In Press).

Calalb, M.B., Polte, T.R., and Hanks, S.K. (1995). Tyrosine phosphorylation of focal adhesion kinase at sites in the catalytic domain regulates kinase-activity - a role for src family kinases. Mol Cell Biol 15, 954-963.

Cappuzzo, F., Magrini, E., Ceresoli, G.L., Bartolini, S., Rossi, E., Ludovini, V., Gregorc, V., Ligorio, C., Cancellieri, A., Damiani, S., et al. (2004). Akt phosphorylation and gefitinib efficacy in patients with advanced non-small-cell lung cancer. J Natl Cancer Inst 96, 1133-1141.

Capron, B., Wattiez, R., Sindic, C., Godaux, E., and Ris, L. (2007). Tyrosine phosphorylation of rabphilin during long-lasting long-term potentiation. Neurosci Lett 414, 257-262.

Carriere, A., Cargnello, M., Julien, L.A., Gao, H., Bonneil, E., Thibault, P., and Roux, P.P. (2008). Oncogenic MAPK signaling stimulates mTORC1 activity by promoting RSK-mediated Raptor phosphorylation. Curr Biol 18, 1269-1277.

Chang, N.S., Doherty, J., Ensign, A., Schultz, L., Hsu, L.J., and Hong, Q.Y. (2005). WOX1 is essential for tumor necrosis factor-, UV light-, staurosporine-, and p53-mediated cell death, and its tyrosine 33-phosphorylated form binds and stabilizes serine 46-phosphorylated p53. J Biol Chem 280, 43100-43108.

Chen, H.C., Appeddu, P.A., Isoda, H., and Guan, J.L. (1996). Phosphorylation of tyrosine 397 in focal adhesion kinase is required for binding phosphatidylinositol 3-kinase. J Biol Chem 271, 26329-26334.

Chen, S.Y., Xu, Y.Y., Yuan, X., Bubley, G.J., and Balk, S.P. (2006). Androgen receptor phosphorylation and stabilization in prostate 
cancer by cyclin-dependent kinase 1. Proc Natl Acad Sci U S A 103, 15969-15974.

Chung, S.H. (2009). Aberrant phosphorylation in the pathogenesis of Alzheimer's disease. BMB Rep 42, 467-474.

Cicenas, J. (2008). The potential role of Akt phosphorylation in human cancers. Int J Biol Marker 23, 1-9.

Clayton, E.L., Sue, N., Smillie, K.J., O'Leary, T., Bache, N., Cheung, G., Cole, A.R., Wyllie, D.J., Sutherland, C., Robinson, P.J., et al. (2010). Dynamin I phosphorylation by GSK3 controls activity-dependent bulk endocytosis of synaptic vesicles. Nat Neurosci 13, 845-U885.

Cohen, P. (2000). The regulation of protein function by multisite phosphorylation--a 25 year update. Trends Biochem Sci 25, 596-601.

Collares-Buzato, C.B., Jepson, M.A., Simmons, N.L., and Hirst, B.H. (1998). Increased tyrosine phosphorylation causes redistribution of adherens junction and tight junction proteins and perturbs paracellular barrier function in MDCK epithelia. Eur J Cell Biol 76, 85-92.

Collawn, J.F. (2006). Unlocking the mysteries of Na+-K+-ATPase endocytosis - Phosphorylation is the key. Am J Resp Cell Mol 35, $1-2$.

Coluccia, A.M.L., Vacca, A., Dunach, M., Mologni, L., Redaelli, S., Bustos, V.H., Benati, D., Pinna, L.A., and Gambacorti-Passerini, C (2007). Bcr-Abl stabilizes beta-catenin in chronic myeloid leukemia through its tyrosine phosphorylation. EMBO J 26, 1456-1466.

Consortium, U. (2012). Reorganizing the protein space at the Universal Protein Resource (UniProt). Nucleic Acids Res 40, D71-D75.

Copp, J., Manning, G., and Hunter, T. (2009). TORC-specific phosphorylation of mammalian target of rapamycin (mTOR): phospho-Ser2481 is a marker for intact mTOR signaling complex 2 . Cancer Res 69, 1821-1827.

Cousin, M.A., Tan, T.C., and Robinson, P.J. (2001). Protein phosphorylation is required for endocytosis in nerve terminals: potential role for the dephosphins dynamin I and synaptojanin, but not AP180 or amphiphysin. J Neurochem 76, 105-116.

D'Alessandris, C., Lauro, R., Presta, I., and Sesti, G. (2007). C-reactive protein induces phosphorylation of insulin receptor substrate-1 on Ser(307) and Ser(612) in L6 myocytes, thereby impairing the insulin signalling pathway that promotes glucose transport. Diabetologia 50, 840-849.

D'Orazi, G., Cecchinelli, B., Bruno, T., Manni, I., Higashimoto, Y., Saito, S., Gostissa, M., Coen, S., Marchetti, A., Del Sal, G., et al. (2002). Homeodomain-interacting protein kinase-2 phosphorylates p53 at Ser 46 and mediates apoptosis. Nat Cell Biol 4, $11-19$.

Dai, N., Rapley, J., Angel, M., Yanik, M.F., Blower, M.D., and Avruch, J. (2011). mTOR phosphorylates IMP2 to promote IGF2 mRNA translation by internal ribosomal entry. Gene Dev 25, 1159-1172.

Dekel, N. (1996). Protein phosphorylation/dephosphorylation in the meiotic cell cycle of mammalian oocytes. Rev Reprod 1, 82-88.

Deming, D., Geiger, P., Chen, H., Kunnimalaiyaan, M., and Holen, K. (2010). ZM336372 induces apoptosis associated with phosphorylation of GSK-3 beta in pancreatic adenocarcinoma cell lines. J Surg Res 161, 28-32.

El Sheikh, S.S., Domin, J., Abel, P., Stamp, G., and Lalani, E.N.
(2004). Phosphorylation of both EGFR and ErbB2 is a reliable predictor of prostate cancer cell proliferation in response to EGF. Neoplasia 6, 846-853.

Fan, H.Y., Tong, C., Chen, D.Y., and Sun, Q.Y. (2002). Roles of MAP kinase signaling pathway in oocyte meiosis. Chinese Sci Bull 47, 1157-1162.

Fan, Y.X., Wong, L.L., and Johnson, G.R. (2005). EGFR kinase possesses a broad specificity for ErbB phosphorylation sites, and ligand increases catalytic-centre activity without affecting substrate binding affinity. Biochem J 392, 417-423.

Feng, H., Hu, B., Liu, K.W., Li, Y., Lu, X., Cheng, T., Yiin, J.J., Lu, S., Keezer, S., Fenton, T., et al. (2011). Activation of Rac1 by Src-dependent phosphorylation of Dock180(Y1811) mediates PDGFRalpha-stimulated glioma tumorigenesis in mice and humans. J Clin Invest 121, 4670-4684.

Fernandez-Borja, M., van Buul, J.D., and Hordijk, P.L. (2010). The regulation of leucocyte transendothelial migration by endothelial signalling events. Cardiovasc Res 86, 202-210.

Ficarro, S.B., McCleland, M.L., Stukenberg, P.T., Burke, D.J., Ross, M.M., Shabanowitz, J., Hunt, D.F., and White, F.M. (2002). Phosphoproteome analysis by mass spectrometry and its application to Saccharomyces cerevisiae. Nat Biotechnol 20, 301-305.

Finn, G., and Lu, K.P. (2008). Phosphorylation-specific prolyl isomerase Pin1 as a new diagnostic and therapeutic target for cancer. Curr Cancer Drug Targets 8, 223-229.

Foster, J.S., and Wimalasena, J. (1996). Estrogen regulates activity of cyclin-dependent kinases and retinoblastoma protein phosphorylation in breast cancer cells. Mol Endocrinol 10, 488-498.

Fujii, S., Kuroda, Y., Ito, K., and Kato, H. (2000). Long-term potentiation induction - A synaptic catch mechanism released by extracellular phosphorylation. Neuroscience 96, 259-266.

Fujita, N., Sato, S., Katayama, K., and Tsuruo, T. (2002). Akt-dependent phosphorylation of p27Kip1 promotes binding to 14-3-3 and cytoplasmic localization. J Biol Chem 277, 28706-28713.

Fujita, N., Sato, S., and Tsuruo, T. (2003). Phosphorylation of p27(Kip1) at threonine 198 by p90 ribosomal protein S6 kinases promotes its binding to 14-3-3 and cytoplasmic localization. J Biol Chem 278, 49254-49260.

Gnad, F., Ren, S.B., Cox, J., Olsen, J.V., Macek, B., Oroshi, M., and Mann, M. (2007). PHOSIDA (phosphorylation site database): management, structural and evolutionary investigation, and prediction of phosphosites. Genome Biol 8.

Gomez, S., Llosas, M.D., Verdu, J., Roura, S., Lloreta, J., Fabre, M., and de Herreros, A.G. (1999). Independent regulation of adherens and tight junctions by tyrosine phosphorylation in Caco-2 cells. Bba-Mol Cell Res 1452, 121-132.

Gual, P., Le Marchand-Brustel, Y., and Tanti, J.F. (2005). Positive and negative regulation of insulin signaling through IRS-1 phosphorylation. Biochimie 87, 99-109.

Haldar, S., Chintapalli, J., and Croce, C.M. (1996). Taxol induces bcl-2 phosphorylation and death of prostate cancer cells. Cancer Res 56, 1253-1255.

Hao, B., Zheng, N., Schulman, B.A., Wu, G., Miller, J.J., Pagano, M., and Pavletich, N.P. (2005). Structural basis of the Cks1-dependent recognition of p27(Kip1) by the SCF(Skp2) ubiquitin ligase. Mol Cell 20, 9-19. 
Head, J.A., Jiang, D.Y., Li, M., Zorn, L.J., Schaefer, E.M., Parsons, J.T., and Weed, S.A. (2003). Cortactin tyrosine phosphorylation requires Rac1 activity and association with the cortical actin cytoskeleton. Mol Biol Cell 14, 3216-3229.

Hirano, K., Hirano, M., and Kanaide, H. (2004). Regulation of myosin phosphorylation and myofilament $\mathrm{Ca} 2+$ sensitivity in vascular smooth muscle. J Smooth Muscle Res 40, 219-236.

Hofmann, T.G., Moller, A., Sirma, H., Zentgraf, H., Taya, Y., Droge, W., Will, H., and Schmitz, M.L. (2002). Regulation of p53 activity by its interaction with homeodomain-interacting protein kinase-2. Nat Cell Biol 4, 1-10.

Hornbeck, P.V., Kornhauser, J.M., Tkachev, S., Zhang, B., Skrzypek, E., Murray, B., Latham, V., and Sullivan, M. (2012). PhosphoSitePlus: a comprehensive resource for investigating the structure and function of experimentally determined post-translational modifications in man and mouse. Nucleic Acids Res 40, D261-D270.

lakoucheva, L.M., Radivojac, P., Brown, C.J., O'Connor, T.R., Sikes, J.G., Obradovic, Z., and Dunker, A.K. (2004). The importance of intrinsic disorder for protein phosphorylation. Nucleic Acids Res 32, 1037-1049.

Itoh, N., Semba, S., Ito, M., Takeda, H., Kawata, S., and Yamakawa, M. (2002). Phosphorylation of Akt/PKB is required for suppression of cancer cell apoptosis and tumor progression in human colorectal carcinoma. Cancer 94, 3127-3134.

Jaggi, M., Rao, P.S., Smith, D.J., Wheelock, M.J., Johnson, K.R., Hernstreet, G.P., and Balaji, K.C. (2005). E-cadherin phosphorylation by protein kinase $\mathrm{D} 1$ protein kinase $\mathrm{C}$ mu is associated with altered cellular aggregation and motility in prostate cancer. Cancer Res 65, 483-492.

Jalkanen, S.E., Vakkila, J., Kreutzman, A., Nieminen, J.K., Porkka, K., and Mustjoki, S. (2011). Poor cytokine-induced phosphorylation in chronic myeloid leukemia patients at diagnosis is effectively reversed by tyrosine kinase inhibitor therapy. Exp Hematol 39, 102-113 e101.

Jiang, C., Hu, H.B., Malewicz, B., Wang, Z.S., and Lu, J.X. (2004). Selenite-induced p53 Ser-15 phosphorylation and caspase-mediated apoptosis in LNCaP human prostate cancer cells. Mol Cancer Ther 3, 877-884.

Jilani, I., Kantarjian, H., Gorre, M., Cortes, J., Ottmann, O., Bhalla, K., Giles, F.J., and Albitar, M. (2008). Phosphorylation levels of BCR-ABL, CrkL, AKT and STAT5 in imatinib-resistant chronic myeloid leukemia cells implicate alternative pathway usage as a survival strategy. Leukemia Res 32, 643-649.

Ju, J.W., Bandyopadhyay, A., Im, W.B., Chung, J., Kwon, H.B., and Choi, H.S. (2002). Involvement of phosphatidylinositol 3 kinase in the progesterone-induced oocyte maturation in Rana dybowskii. Gen Comp Endocr 126, 213-220.

Junttila, M.R., Li, S.P., and Westermarck, J. (2008). Phosphatase-mediated crosstalk between MAPK signalling pathways in the regulation of cell survival. Faseb J 22, 954-965.

Kanamori, Y., Kigawa, J., Itamochi, H., Shimada, M., Takahashi, M., Kamazawa, S., Sato, S., Akeshima, R., and Terakawa, N. (2001). Correlation between loss of PTEN expression and Akt phosphorylation in endometrial carcinoma. Clin Cancer Res 7, 892-895.

Kapoor, M., Hamm, R., Yan, W., Taya, Y., and Lozano, G. (2000).
Cooperative phosphorylation at multiple sites is required to activate p53 in response to UV radiation. Oncogene 19, 358-364.

Karin, M., and Ben-Neriah, Y. (2000). Phosphorylation meets ubiquitination: The control of NF-kappa B activity. Annu Rev Immunol 18, 621-663.

Khadjavi, A., Barbero, G., Destefanis, P., Mandili, G., Giribaldi, G., Mannu, F., Pantaleo, A., Ceruti, C., Bosio, A., Rolle, L., et al. (2011). Evidence of Abnormal Tyrosine Phosphorylated Proteins in the Urine of Patients With Bladder Cancer: The Road Toward a New Diagnostic Tool? J Urology 185, 1922-1929.

Kim, S.J., Rabbani, Z.N., Vollmer, R.T., Schreiber, E.G., Dewhirst, M.W., Vujaskovic, Z., and Kelley, M.J. (2005). Expression of phosphorylated epidermal growth factor receptor ( $p$-EGFR) in early stage non-small cell lung cancer: its relationship with overexpression of EGFR and cyclooxygenase-2 (COX-2), and survival. $\mathrm{J}$ Clin Oncol 23, 864s-864s.

Kim, Y., Paroush, Z., Nairz, K., Hafen, E., Jimenez, G., and Shvartsman, S.Y. (2011). Substrate-dependent control of MAPK phosphorylation in vivo. Mol Syst Biol 7.

Kleinman, D., Karas, M., Danilenko, M., Arbeli, A., Roberts, C.T., LeRoith, D., Levy, J., and Sharoni, Y. (1996). Stimulation of endometrial cancer cell growth by tamoxifen is associated with increased insulin-like growth factor (IGF)-I induced tyrosine phosphorylation and reduction in IGF binding proteins. Endocrinology 137, 1089-1095.

Koepp, D.M., Schaefer, L.K., Ye, X., Keyomarsi, K., Chu, C., Harper, J.W., and Elledge, S.J. (2001). Phosphorylation-dependent ubiquitination of cyclin $\mathrm{E}$ by the SCFFbw7 ubiquitin ligase. Science 294, 173-177.

Konishi, Y., Lehtinen, M., Donovan, N., and Bonni, A. (2002). Cdc2 phosphorylation of BAD links the cell cycle to the cell death machinery. Mol Cell 9, 1005-1016.

Kordowska, J., Huang, R.J., and Wang, C.L.A. (2006). Phosphorylation of caldesmon during smooth muscle contraction and cell migration or proliferation. J Biomed Sci 13, 159-172.

Kornberg, L., Earp, H.S., Parsons, J.T., Schaller, M., and Juliano, R.L. (1992). Cell-adhesion or integrin clustering increases phosphorylation of a focal adhesion-associated tyrosine kinase. J Biol Chem 267, 23439-23442.

Kreisberg, J.I., Malik, S.N., Prihoda, T.J., Bedolla, R.G., Troyer, D.A., Kreisberg, S., and Ghosh, P.M. (2004). Phosphorylation of Akt (Ser(473)) is an excellent predictor of poor clinical outcome in prostate cancer. Cancer Res 64, 5232-5236.

Kruck, S., Bedke, J., Hennenlotter, J., Ohneseit, P.A., Kuehs, U., Senger, E., Sievert, K.D., and Stenzl, A. (2010). Activation of mTOR in renal cell carcinoma is due to increased phosphorylation rather than protein overexpression. Oncol Rep 23, 159-163.

Landry, C.R., Levy, E.D., and Michnick, S.W. (2009). Weak functional constraints on phosphoproteomes. Trends Genet 25, 193-197.

Lee, E.W., Lee, M.S., Camus, S., Ghim, J., Yang, M.R., Oh, W., Ha, N.C., Lane, D.P., and Song, J. (2009). Differential regulation of p53 and p21 by MKRN1 E3 ligase controls cell cycle arrest and apoptosis. EMBO J 28, 2100-2113.

Lee, M.G., Norbury, C.J., Spurr, N.K., and Nurse, P. (1988). Regulated expression and phosphorylation of a possible mammalian cell-cycle control protein. Nature 333, 676-679.

Lee, S.H., Kim, H.S., Park, W.S., Kim, S.Y., Lee, K.Y., Kim, S.H., Lee, 
J.Y., and Yoo, N.J. (2002). Non-small cell lung cancers frequently express phosphorylated Akt; an immunohistochemical study. APMIS 110, 587-592.

Lew, D.J., and Kornbluth, S. (1996). Regulatory roles of cyclin dependent kinase phosphorylation in cell cycle control. Curr Opin Cell Biol 8, 795-804.

Li, Z.L., Li, J.F., Bu, X.N., Liu, X., Tankersley, C.G., Wang, C., and Huang, K.W. (2011). Age-induced augmentation of p38 MAPK phosphorylation in mouse lung. Exp Gerontol 46, 694-702.

Liang, C.G., Su, Y.Q., Fan, H.Y., Schatten, H., and Sun, Q.Y. (2007). Mechanisms regulating oocyte meiotic resumption: roles of mitogen-activated protein kinase. Mol Endocrinol 21, 2037-2055.

Lin, H.Y., Shih, A., Davis, F.B., Tang, H.Y., Martino, L.J., Bennett, J.A., and Davis, P.J. (2002). Resveratrol induced serine phosphorylation of p53 causes apoptosis in a mutant p53 prostate cancer cell line. J Urology 168, 748-755.

Lonart, G., Schoch, S., Kaeser, P.S., Larkin, C.J., Sudhof, T.C., and Linden, D.J. (2003). Phosphorylation of RIM1 alpha by PKA triggers presynaptic long-term potentiation at cerebellar parallel fiber synapses. Cell 115, 49-60.

Ma, D.J., Wang, J.R., Zhao, Y.C., Lee, W.N.P., Xiao, J., Go, V.L.W., Wang, Q., Recker, R.R., and Xiao, G.G. (2012). Inhibition of glycogen phosphorylation induces changes in cellular proteome and signaling pathways in MIA pancreatic cancer cells. Pancreas 41, 397-408.

Mahajan, N.P., Liu, Y., Majumder, S., Warren, M.R., Parker, C.E., Mohler, J.L., Earp, H.S., and Whang, Y.E. (2007). Activated Cdc42-associated kinase Ack1 promotes prostate cancer progression via androgen receptor tyrosine phosphorylation. Proc Natl Acad Sci U S A 104, 8438-8443.

Manabe, T., Aiba, A., Yamada, A., Ichise, T., Sakagami, H., Kondo, H., and Katsuki, M. (2000). Regulation of long-term potentiation by H-Ras through NMDA receptor phosphorylation. J Neurosci 20, 2504-2511.

Manning, G., Plowman, G.D., Hunter, T., and Sudarsanam, S. (2002a). Evolution of protein kinase signaling from yeast to man. Trends Biochem Sci 27, 514-520.

Manning, G., Whyte, D.B., Martinez, R., Hunter, T., and Sudarsanam, $\mathrm{S}$. (2002b). The protein kinase complement of the human genome. Science 298, 1912-1934.

Mathew, R., Hartmuth, K., Mohlmann, S., Urlaub, H., Ficner, R., and Luhrmann, R. (2008). Phosphorylation of human PRP28 by SRPK2 is required for integration of the U4/U6-U5 tri-snRNP into the spliceosome. Nat Struct Mol Biol 15, 435-443.

Matsumoto, H., Sakamoto, A., Fujiwara, M., Yano, Y., Shishido-Hara, Y., Fujioka, Y., and Kamma, H. (2008). Cyclic AMP-mediated growth suppression and MAPK phosphorylation in thyroid papillary carcinoma cells. Mol Med Rep 1, 245-249.

Matsuoka, S., Huang, M.X., and Elledge, S.J. (1998). Linkage of ATM to cell cycle regulation by the Chk2 protein kinase. Science 282 , 1893-1897.

Mayrose, I., Graur, D., Ben-Tal, N., and Pupko, T. (2004). Comparison of site-specific rate-inference methods for protein sequences: empirical Bayesian methods are superior. Mol Biol Evol 21, 1781-1791.

McDonough, W.S., Tran, N.L., and Berens, M.E. (2005). Regulation of glioma cell migration by serine-phosphorylated P311. Neopla- sia 7, 862-872.

McManus, E.J., Sakamoto, K., Armit, L.J., Ronaldson, L., Shpiro, N., Marquez, R., and Alessi, D.R. (2005). Role that phosphorylation of GSK3 plays in insulin and Wnt signalling defined by knockin analysis. EMBO J 24, 1571-1583.

Mermoud, J.E., Cohen, P.T.W., and Lamond, A.I. (1994). Regulation of mammalian spliceosome assembly by a protein-phosphorylation mechanism. EMBO J 13, 5679-5688.

Mimura, Y., Ihn, H., Jinnin, M., Asano, Y., Yamane, K., and Tamaki, K. (2005). Constitutive phosphorylation of focal adhesion kinase is involved in the myofibroblast differentiation of scleroderma fibroblasts. J Invest Dermatol 124, 886-892.

Miyata, Y., Sagara, Y., Kanda, S., Hayashi, T., and Kanetake, H. (2009). Phosphorylated hepatocyte growth factor receptor/c-Met is associated with tumor growth and prognosis in patients with bladder cancer: correlation with matrix metalloproteinase-2 and-7 and E-cadherin. Hum Pathol 40, 496-504.

Morrison, D.K., Murakami, M.S., and Cleghon, V. (2000). Protein kinases and phosphatases in the Drosophila genome. J Cell Biol 150, F57-F62.

Motti, M.L., De Marco, C., Califano, D., Fusco, A., and Viglietto, G. (2004). Akt-dependent T198 phosphorylation of cyclin-dependent kinase inhibitor p27kip1 in breast cancer. Cell Cycle 3, 1074-1080.

Muller, W.A. (2009). Mechanisms of transendothelial migration of leukocytes. Circ Res 105, 223-230.

Mulner, O., Megret, F., Alouf, J.E., and Ozon, R. (1985). Pertussis toxin facilitates the progesterone-induced maturation of Xenopus oocyte. Possible role of protein phosphorylation. FEBS Lett 181, 397-402.

Muslin, A.J., Macnicol, A.M., and Williams, L.T. (1993). Raf-1 protein-kinase is important for progesterone-induced xenopus-oocyte maturation and acts downstream of Mos. Mol Cell Biol 13, 4197-4202.

Mutoh, T., Sobue, G., Hamano, T., Kuriyama, M., Hirayama, M., Yamamoto, M., and Mitsuma, T. (2000). Decreased phosphorylation levels of TrkB neurotrophin receptor in the spinal cords from patients with amyotrophic lateral sclerosis. Neurochem Res 25, 239-245.

Myers, M.G., Mendez, R., Shi, P., Pierce, J.H., Rhoads, R., and White, M.F. (1998). The $\mathrm{COOH}$-terminal tyrosine phosphorylation sites on IRS-1 bind SHP-2 and negatively regulate insulin signaling. J Biol Chem 273, 26908-26914.

Mylonis, I., Chachami, G., Samiotaki, M., Panayotou, G., Paraskeva, E., Kalousi, A., Georgatsou, E., Bonanou, S., and Simos, G. (2006). Identification of MAPK phosphorylation sites and their role in the localization and activity of hypoxia-inducible factor-1 alpha. J Biol Chem 281, 33095-33106.

Nakada, M., Anderson, E.M., Demuth, T., Nakada, S., Reavie, L.B., Drake, K.L., Hoelzinger, D.B., and Berens, M.E. (2010). The phosphorylation of ephrin-B2 ligand promotes glioma cell migration and invasion. Int J Cancer 126, 1155-1165.

Nakada, M., Niska, J.A., Miyamori, H., McDonough, W.S., Wu, J., Sato, H., and Berens, M.E. (2004). The phosphorylation of EphB2 receptor regulates migration and invasion of human glioma cells. Cancer Res 64, 3179-3185.

Nakashima, M., Adachi, S., Yasuda, I., Yamauchi, T., Kawaguchi, J., 
Itani, M., Yoshioka, T., Matsushima-Nishiwaki, R., Hirose, Y., Kozawa, O., et al. (2011). Phosphorylation status of heat shock protein 27 plays a key role in gemcitabine-induced apoptosis of pancreatic cancer cells. Cancer Lett 313, 218-225.

Nebreda, A.R., Gannon, J.V., and Hunt, T. (1995). Newly synthesized protein(s) must associate with $\mathrm{P} 34(\mathrm{Cdc} 2)$ to activate Map kinase and Mpf during progesterone-induced maturation of Xenopus oocytes. EMBO J 14, 5597-5607.

Ng, S.S.W., Tsao, M.S., Nicklee, T., and Hedley, D.W. (2001). Wortmannin inhibits PKB/Akt phosphorylation and promotes gemeitabine antitumor activity in orthotopic human pancreatic cancer xenografts in immunodeficient mice. Clin Cancer Res 7, 3269-3275.

Nigam, S.K., Denisenko, N., Rodriguezboulan, E., and Citi, S. (1991). The role of phosphorylation in development of tight junctions in cultured renal epithelial (Mdck) cells. Biochem Bioph Res Co 181, 548-553.

Nucifora, P.G.P., and Fox, A.P. (1999). Tyrosine phosphorylation regulates rapid endocytosis in adrenal chromaffin cells. J Neurosci 19, 9739-9746.

Oda, A., Miyakawa, Y., Druker, B.J., Ishida, A., Ozaki, K., Ohashi, H., Wakui, M., Handa, M., Watanabe, K., Okamoto, S., et al. (1996). Crkl is constitutively tyrosine phosphorylated in platelets from chronic myelogenous leukemia patients and inducibly phosphorylated in normal platelets stimulated by thrombopoietin. Blood 88, 4304-4313.

Ollila, S., and Makela, T.P. (2011). The tumor suppressor kinase LKB1: lessons from mouse models. J Mol Cell Biol 3, 330-340.

Ou, T.T., Wu, C.H., Hsu, J.D., Chyau, C.C., Lee, H.J., and Wang, C.J. (2011). Paeonia lactiflora Pall inhibits bladder cancer growth involving phosphorylation of Chk2 in vitro and in vivo. J Ethnopharmacol 135, 162-172.

Oude Weernink, P.A., Verheul, E., Kerkhof, E., van Veelen, C.W., and Rijksen, G. (1996). Inhibitors of protein tyrosine phosphorylation reduce the proliferation of two human glioma cell lines. Neurosurgery 38, 108-113.

Park, J., Sung, J.Y., Park, J., Song, W.J., Chang, S., and Chung, K.C. (2012). Dyrk1A negatively regulates the actin cytoskeleton through threonine phosphorylation of N-WASP. J Cell Sci 125, 67-80.

Pinna, L.A., and Ruzzene, M. (1996). How do protein kinases recognize their substrates? Biochim Biophys Acta 1314, 191-225.

Pupko, T., Bell, R.E., Mayrose, I., Glaser, F., and Ben-Tal, N. (2002). Rate4Site: an algorithmic tool for the identification of functional regions in proteins by surface mapping of evolutionary determinants within their homologues. Bioinformatics 18 Suppl 1, S71-77.

Rao, R. (2009). Occludin phosphorylation in regulation of epithelial tight junctions. Ann N Y Acad Sci 1165, 62-68.

Rosner, M., Siegel, N., Valli, A., Fuchs, C., and Hengstschlager, M. (2010). mTOR phosphorylated at S2448 binds to raptor and rictor. Amino Acids 38, 223-228.

Sabile, A., Meyer, A.M., Wirbelauer, C., Hess, D., Kogel, U., Scheffner, M., and Krek, W. (2006). Regulation of p27 degradation and S-phase progression by Ro52 RING finger protein. Mol Cell Biol 26, 5994-6004.

Sakaguchi, K., Sakamoto, H., Lewis, M.S., Anderson, C.W., Erickson,
J.W., Appella, E., and Xie, D. (1997). Phosphorylation of serine 392 stabilizes the tetramer formation of tumor suppressor protein p53. Biochemistry-Us 36, 10117-10124.

Sallee, J.L., and Burridge, K. (2009). Density-enhanced phosphatase 1 regulates phosphorylation of tight junction proteins and enhances barrier function of epithelial cells. J Biol Chem 284, 14997-15006.

Sayers, E.W., Barrett, T., Benson, D.A., Bolton, E., Bryant, S.H., Canese, K., Chetvernin, V., Church, D.M., DiCuccio, M., Federhen, S., et al. (2012). Database resources of the National Center for Biotechnology Information. Nucleic Acids Res 40, D13-D25.

Schaefer, A.W., Kamei, Y., Kamiguchi, H., Wong, E.V., Rapoport, I., Kirchhausen, T., Beach, C.M., Landreth, G., Lemmon, S.K., and Lemmon, V. (2002). L1 endocytosis is controlled by a phosphorylation-dephosphorylation cycle stimulated by outside-in signaling by L1. J Cell Biol 157, 1223-1232.

Schafe, G.E., Swank, M.W., Rodrigues, S.M., Debiec, J., and Doyere, V. (2008). Phosphorylation of ERK/MAP kinase is required for long-term potentiation in anatomically restricted regions of the lateral amygdala in vivo. Learn Memory 15, 55-62.

Schmidt, N., Akaaboune, M., Gajendran, N., Martinez-Pena y Valenzuela, I., Wakefield, S., Thurnheer, R., and Brenner, H.R. (2011). Neuregulin/ErbB regulate neuromuscular junction development by phosphorylation of alpha-dystrobrevin. J Cell Biol 195, 1171-1184.

Serrano, P., Yao, Y., and Sacktor, T.C. (2005). Persistent phosphorylation by protein kinase Mzeta maintains late-phase long-term potentiation. J Neurosci 25, 1979-1984.

Serres, M., Filhol, O., Lickert, H., Grangeasse, C., Chambaz, E.M., Stappert, J., Vincent, C., and Schmitt, D. (2000). The disruption of adherens junctions is associated with a decrease of E-cadherin phosphorylation by protein kinase CK2. Exp Cell Res 257, 255-264.

Shasby, D.M., Ries, D.R., Shasby, S.S., and Winter, M.C. (2002). Histamine stimulates phosphorylation of adherens junction proteins and alters their link to vimentin. Am J Physiol-Lung C 282, L1330-L1338.

Shen, L., Black, E.D., Witkowski, E.D., Lencer, W.I., Guerriero, V., Schneeberger, E.E., and Turner, J.R. (2006). Myosin light chain phosphorylation regulates barrier function by remodeling tight junction structure. J Cell Sci 119, 2095-2106.

Shimada, K., Nakamura, M., Ishida, E., and Konishi, N. (2006). Molecular roles of MAP kinases and FADD phosphorylation in prostate cancer. Histol Histopathol 21, 415-422.

Shouse, G.P., Cai, X., and Liu, X. (2008). Serine 15 phosphorylation of p53 directs its interaction with B56gamma and the tumor suppressor activity of B56gamma-specific protein phosphatase $2 \mathrm{~A}$. Mol Cell Biol 28, 448-456.

Skowyra, D., Craig, K.L., Tyers, M., Elledge, S.J., and Harper, J.W. (1997). F-box proteins are receptors that recruit phosphorylated substrates to the SCF ubiquitin-ligase complex. Cell 91, 209-219.

Slack, B.E. (1998). Tyrosine phosphorylation of paxillin and focal adhesion kinase by activation of muscarinic $\mathrm{m} 3$ receptors is dependent on integrin engagement by the extracellular matrix. Proc Natl Acad Sci U S A 95, 7281-7286.

Slepnev, V.I., Ochoa, G.C., Butler, M.H., Grabs, D., and De Camilli, P. (1998). Role of phosphorylation in regulation of the assembly of 
endocytic coat complexes. Science 281, 821-824.

Soubeyrand, S., Schild-Poulter, C., and Hache, R.J.G. (2004). Structured DNA promotes phosphorylation of p53 by DNA-dependent protein kinase at serine 9 and threonine 18. Eur J Biochem 271, 3776-3784.

Sumi, T., Matsumoto, K., Takai, Y., and Nakamura, T. (1999). Cofilin phosphorylation and actin cytoskeletal dynamics regulated by Rho- and Cdc42-activated LIM-kinase 2. J Cell Biol 147, 1519-1532.

Swain, J.E., and Smith, G.D. (2007). Reversible phosphorylation and regulation of mammalian oocyte meiotic chromatin remodeling and segregation. Soc Reprod Fertil Suppl 63, 343-358.

Sweeney, C., and Carraway, K.L. (2000). Ligand discrimination by ErbB receptors: differential signaling through differential phosphorylation site usage. Oncogene 19, 5568-5573.

Szanto, A., Bognar, Z., Szigeti, A., Szabo, A., Farkas, L., and Gallyas, F. (2009). Critical role of bad phosphorylation by Akt in cytostatic resistance of human bladder cancer cells. Anticancer Res 29, 159-164.

Tang, D., Mehta, D., and Gunst, S.J. (1999). Mechanosensitive tyrosine phosphorylation of paxillin and focal adhesion kinase in tracheal smooth muscle. Am J Physiol-Cell Ph 276, C250-C258.

Tang, J.M., He, Q.Y., Guo, R.X., and Chang, X.J. (2006). Phosphorylated Akt overexpression and loss of PTEN expression in non-small cell lung cancer confers poor prognosis. Lung Cancer 51, 181-191.

Tanti, J.F., and Jager, J. (2009). Cellular mechanisms of insulin resistance: role of stress-regulated serine kinases and insulin receptor substrates (IRS) serine phosphorylation. Curr Opin Pharmacol 9, 753-762.

Terakawa, N., Kanamori, Y., and Yoshida, S. (2003). Loss of PTEN expression followed by Akt phosphorylation is a poor prognostic factor for patients with endometrial cancer. Endocr-Relat Cancer 10, 203-208.

Tinsley, J.H., Wu, M.H., Ma, W.Y., Taulman, A.C., and Yuan, S.Y. (1999). Activated neutrophils induce hyperpermeability and phosphorylation of adherens junction proteins in coronary venular endothelial cells. J Biol Chem 274, 24930-24934.

Topisirovic, I., Ruiz-Gutierrez, M., and Borden, K.L.B. (2004). Phosphorylation of the eukaryotic translation initiation factor elF4E contributes to its transformation and mRNA transport activities. Cancer Res 64, 8639-8642.

Tsurutani, J., Fukuoka, J., Tsurutani, H., Shih, J.H., Hewitt, S.M., Travis, W.D., Jen, J., and Dennis, P.A. (2006). Evaluation of two phosphorylation sites improves the prognostic significance of Akt activation in non-small-cell lung cancer tumors. J Clin Oncol 24, 306-314.

Ubersax, J.A., and Ferrell, J.E., Jr. (2007). Mechanisms of specificity in protein phosphorylation. Nat Rev Mol Cell Biol 8, 530-541.

Ueki, K., Kondo, T., and Kahn, C.R. (2004). Suppressor of cytokine signaling 1 (SOCS-1) and SOCS-3 cause insulin resistance through inhibition of tyrosine phosphorylation of insulin receptor substrate proteins by discrete mechanisms. Mol Cell Biol 24, 5434-5446.

Ueno, M., Carvalheira, J.B.C., Tambascia, R.C., Bezerra, R.M.N., Amaral, M.E., Carneiro, E.M., Folli, F., Franchini, K.G., and Saad,
M.J.A. (2005). Regulation of insulin signalling by hyperinsulinaemia: role of IRS-1/2 serine phosphorylation and the mTOR/p70 S6K pathway. Diabetologia 48, 506-518.

van der Horst, E.H., Weber, I., and Ullrich, A. (2005). Tyrosine phosphorylation of PYK2 mediates heregulin-induced glioma invasion: Novel heregulin/HER3-stimulated signaling pathway in glioma. International Journal of Cancer 113, 689-698.

Vardouli, L., Moustakas, A., and Stournaras, C. (2005). LIM-kinase 2 and cofilin phosphorylation mediate actin cytoskeleton reorganization induced by transforming growth factor-beta. J Biol Chem 280, 11448-11457.

Viatour, P., Merville, M.P., Bours, V., and Chariot, A. (2005). Phosphorylation of NF-kappa B and I kappa B proteins: implications in cancer and inflammation. Trends Biochem Sci 30, 43-52.

Viegi, A., Cotrufo, T., Berardi, N., Mascia, L., and Maffei, L. (2002). Effects of dark rearing on phosphorylation of neurotrophin Trk receptors. Eur J Neurosci 16, 1925-1930.

Viglietto, G., Motti, M.L., Bruni, P., Melillo, R.M., D'Alessio, A., Califano, D., Vinci, F., Chiappetta, G., Tsichlis, P., Bellacosa, A., et al. (2002). Cytoplasmic relocalization and inhibition of the cyclin-dependent kinase inhibitor p27(Kip1) by PKB/Akt-mediated phosphorylation in breast cancer. Nat Med 8, 1136-1144.

Vivanco, I., and Sawyers, C.L. (2002). The phosphatidylinositol 3-kinase-AKT pathway in human cancer. Nat Rev Cancer 2, 489-501.

Vo, K., Amarasinghe, B., Washington, K., Gonzalez, A., Berlin, J., and Dang, T.P. (2011). Targeting notch pathway enhances rapamycin antitumor activity in pancreas cancers through PTEN phosphorylation. Mol Cancer 10, 138.

Volberg, T., Zick, Y., Dror, R., Sabanay, I., Gilon, C., Levitzki, A., and Geiger, B. (1992). The effect of tyrosine-specific protein-phosphorylation on the assembly of adherens-type junctions. EMBO J 11, 1733-1742.

Walker, J.S., Wingard, C.J., and Murphy, R.A. (1994). Energetics of crossbridge phosphorylation and contraction in vascular smooth-muscle. Hypertension 23, 1106-1112.

Wang, C.H., Mao, X.M., Wang, L.X., Liu, M.L., Wetzel, M.D., Guan, K.L., Dong, L.Q., and Liu, F. (2007). Adiponectin sensitizes insulin signaling by reducing p70 66 kinase-mediated serine phosphorylation of IRS-1. J Biol Chem 282, 7991-7996.

Wang, H., Owens, C., Chandra, N., Conaway, M.R., Brautigan, D.L., and Theodorescu, D. (2010). Phosphorylation of RalB is important for bladder cancer cell growth and metastasis. Cancer Res 70, 8760-8769.

Wang, J.J.L., Tasinato, A., Ethell, D.W., Testa, M.P., and Bredesen, D.E. (2000). Phosphorylation of the common neurotrophin receptor $\mathrm{p} 75$ by $\mathrm{p} 38$ beta 2 kinase affects NF-kappa B and AP- 1 activities. J Mol Neurosci 15, 19-29.

Wang, Q., Wang, C.M., Ai, J.S., Xiong, B., Yin, S., Hou, Y., Chen, D.Y., Schatten, H., and Sun, Q.Y. (2006a). Histone phosphorylation and pericentromeric histone modifications in oocyte meiosis. Cell Cycle 5, 1974-1982.

Wang, X., Bruderer, S., Rafi, Z., Xue, J., Milburn, P.J., Kramer, A., and Robinson, P.J. (1999). Phosphorylation of splicing factor SF1 on Ser20 by cGMP-dependent protein kinase regulates spliceosome assembly. EMBO J 18, 4549-4559.

Wang, Y.G., Du, D., Fang, L.H., Yang, G., Zhang, C.Y., Zeng, R., 
Ullrich, A., Lottspeich, F., and Chen, Z.J. (2006b). Tyrosine phosphorylated Par3 regulates epithelial tight junction assembly promoted by EGFR signaling. EMBO J 25, 5058-5070.

Whistler, J.L., Tsao, P., and von Zastrow, M. (2001). A phosphorylation-regulated brake mechanism controls the initial endocytosis of opioid receptors but is not required for post-endocytic sorting to lysosomes. J Biol Chem 276, 34331-34338.

Willems, A.R., Goh, T., Taylor, L., Chernushevich, I., Shevchenko, A., and Tyers, M. (1999). SCF ubiquitin protein ligases and phosphorylation-dependent proteolysis. Philos T Roy Soc B 354, 1533-1550.

Willems, A.R., Lanker, S., Patton, E.E., Craig, K.L., Nason, T.F., Mathias, N., Kobayashi, R., Wittenberg, C., and Tyers, M. (1996). Cdc53 targets phosphorylated $\mathrm{G} 1$ cyclins for degradation by the ubiquitin proteolytic pathway. Cell 86, 453-463.

Wong, Y.H., Lee, T.Y., Liang, H.K., Huang, C.M., Wang, T.Y., Yang, Y.H., Chu, C.H., Huang, H.D., Ko, M.T., and Hwang, J.K. (2007). KinasePhos 2.0: a web server for identifying protein kinase-specific phosphorylation sites based on sequences and coupling patterns. Nucleic Acids Res 35, W588-594.

Xue, Y., Li, A., Wang, L.R., Feng, H.Q., and Yao, X.B. (2006). PPSP: prediction of PK-specific phosphorylation site with Bayesian decision theory. BMC Bioinformatics 7, 163.

Xue, Y., Liu, Z., Cao, J., Ma, Q., Gao, X., Wang, Q., Jin, C., Zhou, Y., Wen, L., and Ren, J. (2011). GPS 2.1: enhanced prediction of kinase-specific phosphorylation sites with an algorithm of motif length selection. Protein Eng Des Sel 24, 255-60.

Yamamoto, N., Mammadova, G., Song, R.X.D., Fukami, Y., and Sato, K. (2006). Tyrosine phosphorylation of p145(met) mediated by EGFR and $\mathrm{Src}$ is required for serum-independent survival of human bladder carcinoma cells. J Cell Sci 119, 4623-4633.

Yu, X.C., and Chen, J.J. (2004). DNA damage-induced cell cycle checkpoint control requires CtIP, a phosphorylation-dependent binding partner of BRCA1 C-terminal domains. Mol Cell Biol 24, 9478-9486.

Zannini, L., Buscemi, G., Kim, J.E., Fontanella, E., and Delia, D. (2012). DBC1 phosphorylation by ATM/ATR inhibits SIRT1 deacetylase in response to DNA damage. J Mol Cell Biol. (In Press).

Zhang, T., Mi, Z.P., and Schor, N.F. (2009). Role of tyrosine phosphorylation in the antioxidant effects of the p75 neurotrophin receptor. Oxid Med Cell Longev 2, 238-246.

Zhang, Y.J., Lu, C.R., Cao, Y., Luo, Y., Bao, R.F., Yan, S., Xue, M., Zhu, F., Wang, Z., and Duan, L.N. (2012). Imatinib induces H2AX phosphorylation and apoptosis in chronic myelogenous leukemia cells in vitro via caspase-3/Mst1 pathway. Acta Pharmacol Sin 33, 551-557.

Zhang, Y.W., Moreland, S., and Moreland, R.S. (1994). Regulation of vascular smooth-muscle contraction-myosin light-chain phosphorylation-dependent and independent pathways. Can J Physiol Pharm 72, 1386-1391.

Zheng, L., Foley, K., Huang, L.Q., Leubner, A., Mo, G.L., Olino, K., Edil, B.H., Mizuma, M., Sharma, R., Le, D.T., et al. (2011). Tyrosine 23 phosphorylation-dependent cell-surface localization of annexin A2 is required for invasion and metastases of pancreatic cancer. Plos One 6, e19390.

Zhou, Y.F., Jiang, H., Tang, J.G., and Tang, B.S. (2008). [The advances in research on phosphorylation of polyglutamine disease]. Zhonghua Yi Xue Yi Chuan Xue Za Zhi 25, 414-417.

Zhu, J.W., Yu, D., Zeng, X.C., Zhou, K., and Zhan, X. (2007). Receptor-mediated endocytosis involves tyrosine phosphorylation of cortactin. J Biol Chem 282, 16086-16094.

Zick, Y. (2001). Insulin resistance: a phosphorylation-based uncoupling of insulin signaling. Trends Cell Biol 11, 437-441.

Zolnierowicz, S., and Bollen, M. (2000). Protein phosphorylation and protein phosphatases. De Panne, Belgium, September 19-24, 1999. EMBO J 19, 483-488. 